\title{
Reading Habits of Selected Communication Educators in Ghana
}

\author{
Gloria Ahima Baffoe Asare Okae-Anti \\ University Of Education, Winneba, P. O. Box 25, Winneba, Ghana
}

\begin{abstract}
This study investigated the intensive and the extensive reading habits of Communication Educators in Ghana. It sought to explore how reading habits enhance the professional and personal lives of the Communication Educators. Questionnaires were used to gather responses from a total of 80 Communication Educators. The findings of this research clearly depict that most of the Communication Educators are not passionate readers considering the fact that they mostly read pedagogical materials in their field of study with minimal concentration on materials which required daily reading to broaden their knowledge base and also for pleasure and relaxation. The findings also revealed the constrains that some of the Educators face in getting current pedagogical textbooks from their various Institutions for the purpose of teaching.
\end{abstract}

Keywords: Reading; Reading habits; Communication Educators.

DOI: $10.7176 / \mathrm{JEP} / 11-3-05$

Publication date: January $31^{\text {st }} 2020$

\section{BACKGROUND}

In assessing the level of literacy of an individual, reading is considered one of the factors. Kumar, Kumar and Rani (2008) posit that the process of reading is the art of interpreting printed and written words. According to Paloni 2012 , reading is the identification of the symbols and the association of appropriate meaning with them and requires identification and comprehension. Reading can also be described as a cognitive process of understanding a written linguistic message and to examine and grasp the meaning of written or printed characters, words or sentences (Lone, 2011).

Reading is the channel to the acquisition of knowledge. Nweke 1990 makes it weightier by stating that reading plays a vital role in the development of the individual. It makes the individual well informed and as Yussif (2007) posits, reading bridges the gap between knowledge and ignorance. The ability to read is the heart of self-education and life-long learning and that is an art capable of transforming life and society (Tella \& Akande, 2007).

Through reading, individuals make advancement in their personal and emotional development. Their knowledge base is enhanced, intellect sharpened and misconceptions are eroded (Nkiko \& Yussif, 2006). Information derived through vast reading shape readers' mental abilities and further lay foundation to their social, economic and civic lives (Clark \& Rumbold, 2006). Reading provides the experience through which the individual may expand his horizons of knowledge, identity; extend and intensify his interest so as to gain deeper understanding of himself (Rout \& Chettri, 2013). Reading is a conscious literacy process that influences the extent and accuracy of information as well as attitudes, beliefs and judgement of a reader (Panigrahi \& Panda, 1996).

Even though reading tremendously transforms readers, individuals are not in recent times aware of issues surrounding them due to low patronage of reading. The Hindu $(2004$, p.1) states that that "In an age when browsing the net, playing with funky handsets and passing non-stop SMSs seem to be the order of the day, reading a book in a peaceful corner of a library has become an archaic idea for most people. While technology is slowly taking a steady control over individual lives, the reading habit is fast vanishing into thin air". Palani(2012) affirms this view indicating that due to the strong presence of social media, people do not show much interest in reading books, magazines, newspapers, journals among others. For one to be full of knowledge and develop critical thinking capabilities, reading should be a habit. Developing sustained reading serve as a tool for humans to transmit knowledge derived to succeeding generations (Okebukola, 2004).

Reading habit stimulates the promotion of one's personal development and social progress in general. This habit is usually considered in relation to the amount of materials read, the frequency of reading and also the average of time spent on reading (Wagner, 2002). According to Purgaiah 2016, reading habit depicts the behaviour which expresses the likeness of reading of individual types of reading and tastes of reading. Therefore a reader can merely read for pleasure while another can read for getting information (Ogeyik, 2008). Ayyildiz et al (2006) further state that some common factors such as individual's interest, culture, gender and occupation all determine their preferences of reading. Spending time on a particular genre of book depicts what a person is interested in. The contents in books read usually can make or unmake a person. This is how powerful knowledge is.

\section{STATEMENT OF THE PROBLEM}

Educators or teachers play vital roles in moulding future students. They are the authority figures who impart knowledge to learners. As captured by (Olajide, 2008) teachers are the chief drivers of the education engine. As engineers of education it is expected that they read habitually as a sign of professional interest to raise their standard 
or read for pleasure? Empirical studies off shore Ghana shows less interest in reading by teachers. For instance, Hassen (2016) explored the reading habits of secondary school teachers in Addis Ababa and Dessie on a sample of 54 through questionnaire and in-depth interview. It showed that the teachers read purposely for examinations and classroom delivery but rarely from newspapers and some websites as a form of extensive reading to broaden their knowledge. Adebayo (2009) also conducted a study on the reading habits of High school teachers in Nigeria on a sample of 100 through questionnaire. The findings revealed that majority of the teachers that were sampled read textbooks daily. Oluwabiyi and Adetunji (2018) examined the reading habits of teachers from some selected schools in Nigeria on the development of Reading culture in students. The findings sampled revealed that most teachers do not have fixed time for reading and only few of them read for pleasure, to pass an exam or to write a lesson note. Hence their reading habits do not have far reaching effects on the reading habits of their students.

In the Ghanaian context, research on reading habits has mostly been done on students and not on Educators. For instance, Agbenyega (2016) investigated the role of internal and external factors in the cultivation of life-long reading habits of Tweenagers in Accra. Data was collected from 187 tweenagers (students) from three basic schools in Accra. Her findings revealed that students read for pleasure, for information and learning purposes.

Pobi (2016) also conducted a study on the reading habits and its effect on academic performance of students of St John's Grammar Senior High School, Accra. Findings from the 133 students sampled for the study revealed that majority of the students acknowledged the importance of reading and the purpose for which they read was to improve vocabulary and pass their exams and then for pleasure.

Again in an article posted on Graphic Online on 24th September, 2015, Agyemang-Duah stated that the evidence of a deteriorating reading culture is very obvious in the Ghanaian society. He expressed worry about the declined numbers of Ghanaians often found reading Newspapers, newsletters, magazines or books while idle or on a journey. He again identified the waning number of publishing houses and newspaper subscriptions and readers as well as the dwindled numbers and use of public libraries in Ghana.

This low interest in reading has made it necessary to explore the reading habits of Educators who imparts knowledge to students. The lens is precisely on Communication Educators who have reading as part of the curriculum to teach students and how they have developed or built their mental capacities enough through reading for best professional practices. Trelease (2006) observes that teachers seldom read. A good teacher must have a broad information base and not depend on their lesson notes which contain all the information on a given topic (Palani, 2012).

This research therefore sought to investigate the intensive and the extensive reading habits of the Communication Educators in Ghana and how their reading habits enhance their professional and personal lives.

\section{OBJECTIVES OF THE STUDY}

This research sought to achieve the following objectives:

1. To investigate how often Ghanaian Communication Educators read.

2. To verify the purpose for which Ghanaian Communication Educators read.

3. To identify the genre of books Ghanaian Communication Educators read.

\section{METHODOLOGY}

This is a survey. A questionnaire was used to gather data. The sample population of the study was all lecturers teaching communication related courses in accredited institutions in Ghana who are members of the Communication Educators Association of Ghana (CEAG). Forty-nine out of eighty members who were part of a WhatsApp group created for CEAG members participated in this study.

The researcher collected and analysed data through Google forms. Google forms were used as a platform to create a self -prepared online questionnaire with 3 sections: Bio-data, Extensive reading and Intensive reading. There were 25 closed-ended questions and 5 open-ended questions in all. The questionnaire was automatically hosted through a unique URL. Access to the URL link was protected by a password. Again, a unique study ID gave participants access to the URL link to participate. The ID also ensured confidentiality of data. Responses from participants were secured using a cloud database where data was sorted, scaled, scored and imported to excel spreadsheets.

Google forms permit online data analysis and graphical presentation. So, when participants filled the web questionnaire, online data was automatically recorded in Google spreadsheet in an analyzable manner which allowed for tabulation and graphical representation of data. The researcher downloaded questionnaire responses in excel which were then analysed and interpreted.

\section{RESULTS}

The results of the study were presented to address the objectives of the study. 
Objective 1: To investigate how often Ghanaian Communication Educators read.

Pleasure in extensive reading

\begin{tabular}{|l|l|l|}
\hline Do you find pleasure reading extensively & Frequency & Percentage \\
\hline Yes & 45 & 91.8 \\
\hline No & 4 & 8.2 \\
\hline Total & 49 & 100.0 \\
\hline
\end{tabular}

Clark and Rumbold (2006) define pleasure reading as reading that is done on individual's free will as a result of the satisfaction he/she gets from the act of reading. As highlighted in the table above, majority of the respondents, 45(91.8), indeed, found pleasure reading extensively while 4(8.4) of the respondents answered in the negative.

Reading outlook of respondents within three months

\begin{tabular}{|l|l|l|}
\hline Within the past three months have you read a book lately? & Frequency & Percentage \\
\hline Yes & 43 & 87.8 \\
\hline No & 6 & 12.2 \\
\hline Total & 49 & 100.0 \\
\hline
\end{tabular}

Reading is a conscious literacy that influences the extent and accuracy of information as well as attitudes, beliefs and judgement of a reader (Panigrahi \& Panda, 1996). It is an activity that must be done continuously. For we learn to read by reading (Smith, 1994a, p.178, cited in Mikeladze, 2014) In an attempt to verify the reading outlook of respondents within the past three months that the research was conducted, most of them 43(87.8) had read a book while 6(12.2) indicated that they had not read any book within that period.

Frequencies of book reading

\begin{tabular}{|l|l|l|}
\hline How often do you read a book? & Frequency & Percentage \\
\hline Once a month & 22 & 44.9 \\
\hline Once in 3/4 months & 22 & 44.9 \\
\hline Once a year & 5 & 10.2 \\
\hline Total & 49 & 100.0 \\
\hline
\end{tabular}

According to Hedge (2002, p.202) extensive reading is reading consistently overtime on a frequent and regular basis. Additionally, Krashen (1993, cited in Dogan, 2014) argues that people who read frequently possess stronger overall literacy skills, such as larger vocabularies, improved writing ability, better spelling and increased knowledge of grammatical and punctuation rules. It is expected that as Communication Educators who teach Reading as part of the Curriculum, frequent reading of books would be top priority. However, results from the study exhibited on the table above showed that 22(44.9) of the respondents who were devoted to reading, read a book once in a month, 22 (44.9) of the respondents also read a book once in3/4 months and only 5(10.2) of the respondents read a book once a year.

The amount of books respondents read within a year.

\begin{tabular}{|l|l|l|}
\hline How many books are you able to read within a year? & Frequency & Percentage \\
\hline $1-2$ & 16 & 32.7 \\
\hline $3-4$ & 16 & 32.7 \\
\hline $5-6$ & 16 & 32.7 \\
\hline None & 1 & 2 \\
\hline Total & 49 & 100.0 \\
\hline
\end{tabular}

A good teacher should keep abreast with information. Information derived through vast reading shape readers mental abilities and further lay foundation to their social, economic and civil lives (Clark \& Rumbold, 2006). Responses from the questionnaire showed no difference in terms of frequency on the number of books read within a year. In fact, about 65.4 respondents read between 1-4 books within a year, 32.7 respondents read between 5-6 books within a year while only 1 respondent said she or he had not read any book within a year. This result corroborates Trealease (2006) view that teachers seldom read. A good teacher must have a broad base and not depend on their lesson notes which contain all the information on a given topic (Palani, 2012).

Format used during extensive reading.

\begin{tabular}{|l|l|l|}
\hline Which formats do you read? & Frequency & Percentage \\
\hline Online & 4 & 8.2 \\
\hline Hard copy & 12 & 24.5 \\
\hline Both & 33 & 67.3 \\
\hline Total & 49 & 100.0 \\
\hline
\end{tabular}

The table above showed that 4 (8.2) respondents who were internet savvies preferred to read books online, 12(24.5) read hard copies and 33(67.3) enjoyed reading from both soft and hard copies. 
Time spent on extensive reading.

\begin{tabular}{|l|l|l|}
\hline How much time do you spend reading? & Frequency & Percentage \\
\hline Up to I hour & 12 & 24.5 \\
\hline $1-2$ hours & 18 & 36.7 \\
\hline 2-3 hours & 9 & 18.4 \\
\hline 3-4 hours & 10 & 20.4 \\
\hline Total & 49 & 100.0 \\
\hline
\end{tabular}

Results from the table above indicated that 12(24.5) of the respondents spent up to an hour to read a book, 18(36.7) which is the bulk of the readers, in this table spent 1-2 hours reading a book , 9(18.4) spent 2-3 hours reading, while 10(20.4) spent 3-4 hours reading a book.

Time spent on intensive/detailed reading.

\begin{tabular}{|l|l|l|}
\hline How much time do you spend on intensive/detailed reading? & Frequency & Percentage \\
\hline $1-2$ hours & 24 & 49 \\
\hline 2-3 hours & 12 & 24.5 \\
\hline $3-4$ hours & 13 & 26.5 \\
\hline Total & 49 & 100.0 \\
\hline
\end{tabular}

According to Palmer (1921, cited in Nation, 2009) intensive reading is for accuracy. It is reading for high degree of comprehension and retention over a long period of time. What this means is that intensive reading is not for general information or for pleasure and therefore requires enough time to achieve accuracy. However, the results from the table above revealed that only13(26.5) of the respondents spent between 3-4 hours doing detailed reading in anticipation for their teaching in class, followed by $12(24.5)$ respondents who spent between 2-3 hours reading, while majority of the respondents 24 (49) spent between 1-2 hours enriching themselves with knowledge through reading before instructional hours. Perhaps people in this category (1-2 hours) can restructure and spend more time on intensive reading.

Publication read in a year.

\begin{tabular}{|l|l|l|}
\hline How many publications do you read in a year? & Frequency & Percentage \\
\hline Between10-20 publications & 39 & 79.6 \\
\hline Less than 10 publications & 10 & 20.4 \\
\hline Total & 49 & 100.0 \\
\hline
\end{tabular}

Publication in academia is of utmost importance. Engaging in empirical research and being informed through that, is key to any academic because reading articles provide the experience through which that individual may expand his horizon of knowledge, identity; extend and intensify his interest so as to gain deeper understanding of himself ( Chettri \& Rout, 2013). Results from respondents as presented in the table above showed that 39(79.6) of them read more than 10 publications in a year while 10(20.4) of them said they read less than 10 publications.

Usefulness of intensive reading

All respondents in the study responded in the affirmative. They stated that engaging in intensive reading before lecturing had become very useful since it gave them current divergent views on a subject matter and built their confidence to make effective lesson delivery.

Objective 2: To verify the purpose Ghanaian Communication Educators read.

Purpose of reading extensively

Longman Dictionary of Language teaching of Applied Linguistics defines extensive reading as a skill that is "intended to develop good reading habits, to build vocabulary and structure and encourage a liking for reading" (Richards et al, 2002; Platt \& Platt,1992, p.133) All respondents (100.0) responded to this question. Results from data gathered revealed that a lot of the respondents read based on significance. For instance, $91.8 \%$ read mostly for general information, $51 \%$ read for pleasure, $40.8 \%$ read mainly to build vocabulary, $20.4 \%$ read to understand grammar, 24.5 read to build fluency while read to build their reading speed. However, $6.1 \%$ of the respondents said though they read extensively, they do not subscribe to any of the reasons provided in the questionnaire.

Relevance of instructional books from institutions

Textbooks are the heart of educational enterprise, as they offer "a rich array of new and potentially interesting facts and open the door to the world of fantastic experience" (Chambliss \& Calfee, 1998. p.7 cited in Mohammad \& Kumari, 2007), and since books play these notable roles in life, it is expected that institutions who work in partnership with teachers stock their libraries with appropriate books that will be beneficial to the progress of both teachers and students. All respondents answered this question with most of them agreeing to the fact that books provided by their various Institutions for instructional teaching were very relevant because they served as reference materials for courses they teach, they also served as the foundation for every course for students and again complemented the tacit knowledge of teachers. The rest of the respondents said the books were fairly relevant because some of the contents were outdated thus, preferred using their personal library or opted for online resources. 
Objective 3: To identify the genre of books Ghanaian Communication Educators read.

Genre/type of books Respondents prefere to read

\begin{tabular}{|l|l|l|}
\hline $\begin{array}{l}\text { What genre/type of book do you prefere reading? } \\
\text { Tick as many as relevant. }\end{array}$ & Frequency & Percentage \\
\hline Communication & 41 & 83.7 \\
\hline Religious & 16 & 32.7 \\
\hline Politics & 19 & 38.8 \\
\hline Romantic & 6 & 12.2 \\
\hline Economy & 4 & 8.2 \\
\hline Comic & 6 & 12.2 \\
\hline Newspapers & 26 & 53.1 \\
\hline Others & 16 & 32.7 \\
\hline Total & & \\
\hline
\end{tabular}

Responses from the table shown above indicated that 41(83.7) of the respondents had high interest in reading Communication books and this might be attributed to the fact that they are Communication Educators. Respondents who could be classified as passionate readers from the view point that they subscribe to reading Newspapers daily, were 26(53.1). 19(38.8) of the respondents read books on politics, for respondents who had interest in reading religious books the results showed they were16(32.7). Interestingly, respondents who read other books apart from what was lined up were also 16(32.7). The figures and percentage for respondents who read Romantic and Comic book also were same i.e., 6(12.2). However, respondents who mostly had developed love for books with contents based on the Economy were 4(8.2).

Books used by teachers for instructional teaching

It was revealed from the findings that $34.7 \%$ of the respondents bought hard copies of the textbooks they use for teaching in their various Institutions. $28.6 \%$ bought $\mathrm{E}$ books or read online, $24.5 \%$ were fortunate to get their textbooks from their Institutions and 12.2\% said they borrowed textbooks from friends to teach.

Access to textbooks from institutions

It has been identified that access and availability of textbooks is a particularly significant factor in predicting academic achievement (Heyman et al, 1978, cited in Oaks \& Saunders, 2004). However, from the results of the study 33(67.4) of the respondents, revealed that textbooks for Faculty to teach were never available in the Institutions library. The remaining 16(32.6) said even though textbooks were readily available in the Institution's library, they were of low standards.

Current or updated versions of textbooks or materials for teaching

\begin{tabular}{|l|l|l|}
\hline $\begin{array}{l}\text { Does the Institution provide current or updated versions of the textbooks or materials } \\
\text { for teaching? }\end{array}$ & Frequency & Percentage \\
\hline Yes & 18 & 38.3 \\
\hline No & 29 & 61.7 \\
\hline Total & 49 & 100.0 \\
\hline
\end{tabular}

As exhibited in the table above, 18(38.3) of the respondents confirmed that current versions textbooks were provided for teaching by the various Institutions while 29(61.7) responded in the negative.

Measures put in place by teachers to get updated versions

\begin{tabular}{|l|l|l|}
\hline If No, what measures do you put in place to get updated versions? & Frequency & Percentage \\
\hline Buy updated hard copy of textbooks. & 15 & 30.6 \\
\hline Search/purchase/subscribe to updated version of textbook online. & 25 & 51.0 \\
\hline Prefere not to speak & 9 & 18.4 \\
\hline Total & 49 & 100.0 \\
\hline
\end{tabular}

The results highlighted on the table above showed that 15(30.6) of the respondents usually, bought current hard copies of textbooks for teaching anytime their Institutions failed to provide for them, 25(51.0) resorted to updated versions of textbook online. However, 9(18.4) said the preferred not to reveal the plans they put in place to salvage the situation.

Sources teachers consult for academic work

\begin{tabular}{|l|l|l|}
\hline What are the sources you consult for academic work? & Frequency & Percentage \\
\hline Books & 4 & 8.2 \\
\hline Articles & 10 & 20.4 \\
\hline Both & 35 & 71.4 \\
\hline Total & 49 & 100.0 \\
\hline
\end{tabular}

The table above showed that 4(8.2) of the respondents consulted only books for academic work, 10(20.4) consulted only journal articles while 35(71.4) consulted both books and journal articles for academic work. 


\section{DISCUSSION}

The results from data collected for this study suggest that every Ghanaian Communication Educator engage in some reading. However, if Saglamtunç(1990 and Yilmaz, 1995 cited in Doğan, 2014) classification of book readers based on the criteria of frequencies of book reading suggested by American Library Association (ALA, 1978) is to be considered, then it can be concluded that Ghanaian Communication Educators are low frequency readers. According to the classifications, a low frequency reader reads 1-5 books per year, a low-middle frequency reader reads 6-11 books per year, a high middle frequency reader reads 12 to 20 books per year and a high frequency reader reads more than 21 books per year. Perhaps teachers would consider growing more desire and interest in reading books to develop their careers, maintain their knowledge of children's literature and encourage their students to read by acting as role models (Cecil, 2010).

It can additionally, be said that Ghanaian Communication Educators engage in reading for general knowledge and for pleasure and this corroborates Susser and Robb (1990, cited in Mikeladze, 2014) view of extensive reading, that it is reading for general understanding and also with the intention of obtaining pleasure from the text. With regards to provision of textbooks for instructional teaching, teachers admitted that textbooks provided by their various institutions are relevant and fit their purpose of reading them because they play the role as "primary vehicles for delivering content knowledge, for determining in large quantities what goes on in class"(Hummel, 1998, cited in Lebrun et al, 2002).

According to Hedge $(2000$, p.202) extensive reading is reading large quantities of materials such as short stories and novel, newspaper and magazine, articles or professional reading. It is again evident from the results obtained from the survey that respondents have the flair for reading varieties of books for professional and for relaxation purposes. And in their quest for knowledge they do not only rely on reading from hardcopy books but read publications and books from online as well. However, in order not for them to be limited to their subject knowledge as suggested by the results of the survey, Communicated Educators could spread their tentacles to read more of other genres of books other than communication. Institutions could also increase students and teachers' knowledge and exposure by making current or updated textbooks available for academic progression.

\section{CONCLUSION}

Reading habit stimulates the promotion of one's personal development and social progress in general. This habit is usually considered in relation to the amount of materials read, the frequency of reading and also the average time spent on reading (Wagner, 2002). The findings of this research clearly depict that most of the Communication Educators are not passionate readers considering the fact that they mostly read pedagogical materials in their field of study with minimal concentration on materials that required daily reading to broaden their knowledge base and also for pleasure and relaxation. Findings also revealed, constrains some of the Educators face in getting current pedagogical textbooks from their various Institutions to lecture in class.

\section{REFERENCES}

Adebayo, O. (2009) Reading Habits of lyceum Teachers: A Study of Selected Secondary Schools in Ado-Odo Ota Local government Area. Library Philosophy and Practice (e-journal). Paper 290. http://digitalcommons.unl.edu/libphilprac/290

Agyemang-Duah, E., (2015). Empowering Ghana through Reading. Daily Graphic Online.

Thursday, September, 24. Retrieved from http://graphic.com.gh

Ayyıldız M., Bozkurt Ü., \& Canlı S. (2006). Okuma Kültürü Üzerine Bir Araştırma. Retrieved November 19, 2008 from http://yayim.meb.gov

Cecil, M. A (2010). Education Majors' text reading habits: How much are they reading? National Social Science Journal, 35(1), 14-22

Chettri, M. K. \& Rout, S. K. (2013). Reading Habits - An Overview. IOSR Journal of humanities and Social Science, 14(6), 13-17. Retrieved from http://www.iosrjournals.org

Clark, C. \& Rumbold, K. (2006). Reading for pleasure: a research overview. Retrieved from http://www.literacytrust.org

Doğan, B. (2014). Prospective teachers' reasons: the Importance of Reading a book. Bilgi Dunyasi. 15(1), 159175 .

The Hindu (2004). Whither the reading habit? Online India's National Newspaper, Monday, July 12. Available: http://www.hinduonnet.com

Hedge, T. (2000). Teaching and Learning in the Language Classroom. Oxford:OUP.

Kumar, R. S., Kumar, A. S. \& Swaroop Rani, B. S. (2008). Reading Habits Among the varsity Children in Northern District of Tamil Nadu, India. Ida Scudda, Vellore, INDIA., Department of Library \& Information Science, Bishop Heber College, Titruchirappali, INDIA. senthil_abey@sify.com

Lone, F. A. (2011). Reading Habits of Rural and concrete College Students within the 21st Century. Library Philosophy and Practice. Retrieved from http://digitalcommons.unl.edu/libphilprac/586. 
Lebrun, J., Lenori, Y., Laforest, M., Larose, F., Roy, G. R., Spallanzani, C. \& Pearson, M. (2002) Past and current trends in the analysis of textbooks in a Quebec context. Curriculum Inquiry, 32(1), 51-83

Mikeladze, T. (2014). Extensive Reading. Tbilisi: Universal.

Mohammad, F. R., \& Kumari, R. (2007). Effective Use of Textbooks: A Neglected Aspect of Education in Paskistan. Journal of Education for International Development, 3(1).

Nation, I.S.P. (2009). Teaching ESL/EFL Reading and Writing. New York: Routledge.

Nkiko, C. \& Yusuf, F.O. (2006). Bibliotherapy and aging among Covenant University Staff. Ife, Psychologia 14 (1), 133-147.

Oakes, J. \& Saunders, M. (2004). Education's most elementary tools: access to textbooks and instructional materials in California's public schools. Teachers College Record, 106(10), 1967-1988

Ögeyik M. C. (2008). Metinlerarasılık ve Yazın Ĕ̆itimi. Ankara: Anı Yayıncılık

Okebukola, F. O. (2004) "Reading key to lifelong development”. A key note address delivered at the workshop on readership promotion campaign organized by the National Library of Nigeria, Lagos

Olajide, O. (2008). Teachers in Nigeria's Education Industry. Punch on the Web Available: http://www.punchng.com

Palani, K. K. (2012). Promising Reading Habits and Creating Literate Social. International Reference Research Journal. 2(1), 91.

Poosapati, P. (2016). Reading Habits among students teachers with respect to Gender and Qualification. International Journal for Educational Research Studies. 11 (8).

Susser, B., \& Robb, T. N. (1990). EFL extensive reading instruction: Research and procedure. JALT Journal, 12(2)

Richards, J. C., Schmidt, R., Kendricks, H., \& Kim, Y. (2002). Longman Dictionary of Language Teaching and Applied Linguistics. (Eds.). Pearson Education Limited. London. UK.

Tella, A., \& Akande, S. (2007). Children's reading habits and availability of books in Botswana primary schools: Implications for achieving quality education. The Reading Matrix. 7 (2)

Trelease, J. (2006). How non-reading students are associated with their non-reading parents and teachers. Available: http://www.treleaseon-reading.com

Wagner, S. (2002). The reading habits of teams. Journal of Reading Today, (46), 3-4.

Yusuf, F. (2007). Repositioning school libraries in Nigeria: The catalyst for promoting reading habits among primary and lyceum students. Library Philosophy and Practice. [Online] Available: www.urillib.unil.edu/../adebayo-oyeronke.htm (16 December, 2011) 